\title{
Flatmarksmiler i Vestnes fra yngre jernalder og middelalder
}

Den mest kjente metoden for kullfremstilling i yngre jernalder og middelalder i Norge er brenning i grop. Kullgroper er blant de vanligste kulturminnene i landet, og de er spesielt utbredt på Østlandet. Særlig tallrike er de i perioden 900-1450/1500 e.Kr. (Bloch-Nakkerud 1987:126-139; Larsen 2004:154; 2009:66), for gradvis å bli avløst av flatmarksmiler (reismiler og liggemiler) i etterreformatorisk tid (Narmo 1996b, 1997). Mens flatmarksmilene blant annet kobles sammen med bergverkene, forbindes kullgropene gjerne med jernvinna. Selv om smikull også ble fremstilt i kullgroper, ble de først og fremst anvendt for å produsere kull til blestringen i sjaktovnene med slaggavtapping i vikingtid og middelalder (Damlien og Rundberget 2007; Narmo 1996b, 1997; Rundberget 2013).

I sterk kontrast til Østlandet er det kun blitt dokumentert et beskjedent antall kullgroper i Møre og Romsdal - cirka femten i alt. Den største kjente samlingen består av fem kullgroper som knyttes til smedvirksomheten ved kaupangen på Veøya (Herteig 1953, 1954; Solli 1996). Tolv av kullgropene i Møre og Romsdal er blitt radiologisk datert. Indikasjonen fra dette noe tynne datagrunnlaget er at kullbrenning i grop kronologisk sett hører hjemme i høymiddelalderen og senmiddelalderen - i en periode da de siste sporene etter jernfremstilling i fylket har opphørt. Ettersom man må ha hatt behov for kull i sammenheng med metallurgisk virksomhet gjennom jernalderen og middelalderen - både i forbindelse med smiing og i sammenheng med jernfremstillingsprosessen i enkelte typer sjaktovner - har mangelen på spor etter kullproduksjon i Møre og Romsdal representert et kunnskapshull.

I 2015-2016 påviste Møre og Romsdal fylkeskommune seksten kullforekomster på flatmark i et utmarksområde i Vestnes kommune. Kullforekomstene målte inntil 13 m i diameter, og besto av inntil $50 \mathrm{~cm}$ tykke, ensartede kullag. Dateringsspennet varierte fra merovingertid til høymiddelalderen. I det samme området ble det også påvist fire nye jernvinneanlegg fra samme periode.

I denne artikkelen vil vi drøfte en mulig tolkning av kullforekomstene som levninger etter flatmarksmiler knyttet til jernvinna. Vi mener materialet fra Møreaksen-prosjektet kan være en nøkkel for å forstå kullfremstillingen i Møre og Romsdal i yngre jernalder og i middelalderen. En vesentlig årsak til at man tidligere ikke har hatt kjennskap til fremstillingen 
av kull på flatmark i disse periodene, kan være at milene levner få eller ingen visuelle avtrykk i utmarkslandskapet.

\section{Møreaksen-prosjektet}

I forbindelse med planleggingen av ny E39 over Romsdalsfjorden gjennomførte Møre og Romsdal fylkeskommune et større registreringsprosjekt i 2015-2016 under tittelen «Møreaksen» (Eidshaug 2016a, 2016b, 2016c).

Sporene etter jern- og kullfremstilling ble alle funnet sentralt på halvøya mellom Tomrefjorden og Tresfjorden i Vestnes kommune (figur 1). Området består for det meste av flatt eller svakt hellende utmarksterreng, i tillegg til noe nydyrket myr. Terrenget kjennetegnes især ved den nord-sør-orienterte vekslingen mellom lave, men tørre furukledde morenerygger og våte myrdrag med mer varierende vegetasjon. Der podsol karakteriserer tørrdragene, ser man antydninger til at myrene er særdeles malmrike ved den tydelige utfellingen i bekker og kanaler.

Innen prosjektstart var det registrert et jernfremstillingsanlegg, Sinderhaugen, fra eldre romertid, samt en kullforekomst av ukjent art innenfor planområdet (Narmo 1992; se også Tveiten 2005:40-41). I løpet av prosjektet ble det funnet fire nye jernvinneanlegg, to kullgroper og seksten «kullforekomster» (Eidshaug 2016a:111-208, 267-276), se figur 2. Begrepet «kullforekomster» benyttes til å omtale mektige, ensartede kullag påvist på flatmark, som vi senere argumenterer for at representerer levninger etter kullfremstilling. Ettersom de nye jernvinneanleggene er viktige for forståelsen av kullforekomstene i Vestnes, vil vi først kort introdusere dem.

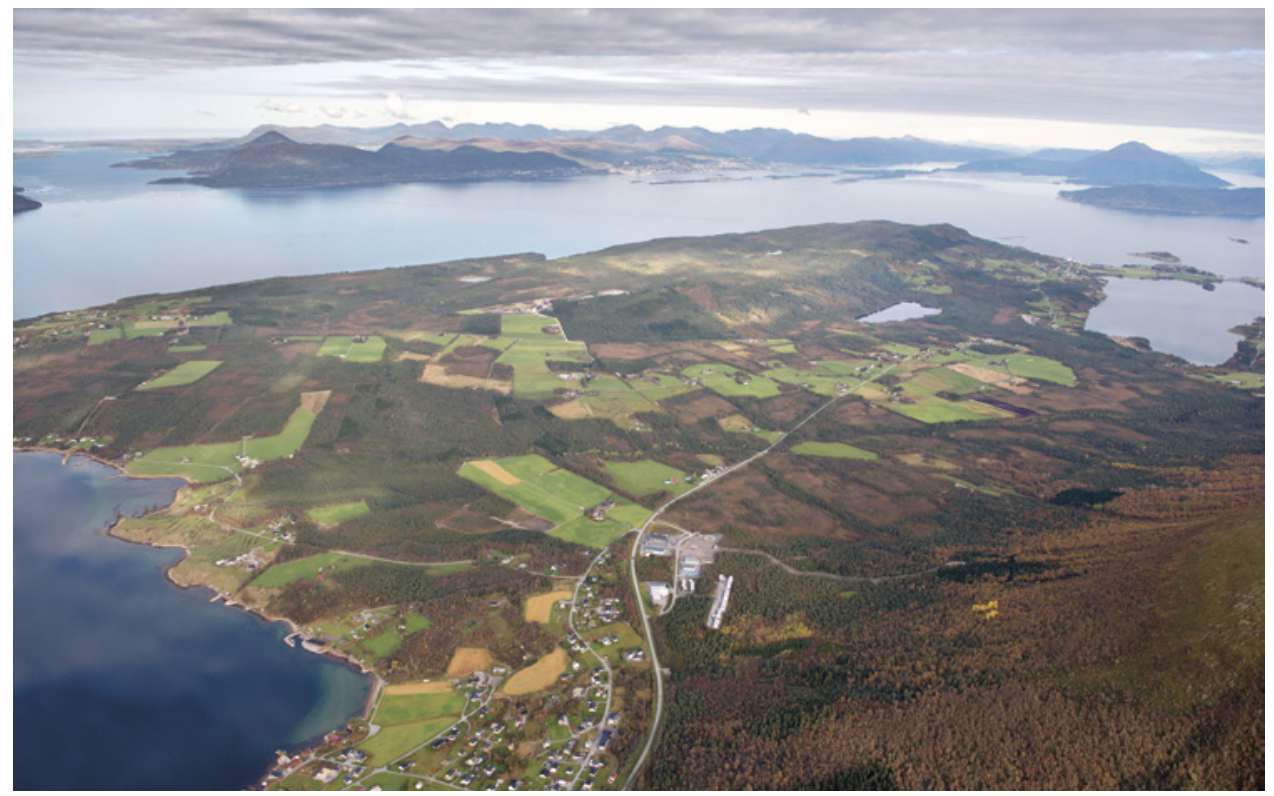

Figur 1. Flyfoto av undersøkelsesområdet $i$ Vestnes i forbindelse med «Møreaksen». Molde skimtes i bakgrunnen. Foto: Øivind Leren, Statens vegvesen. 


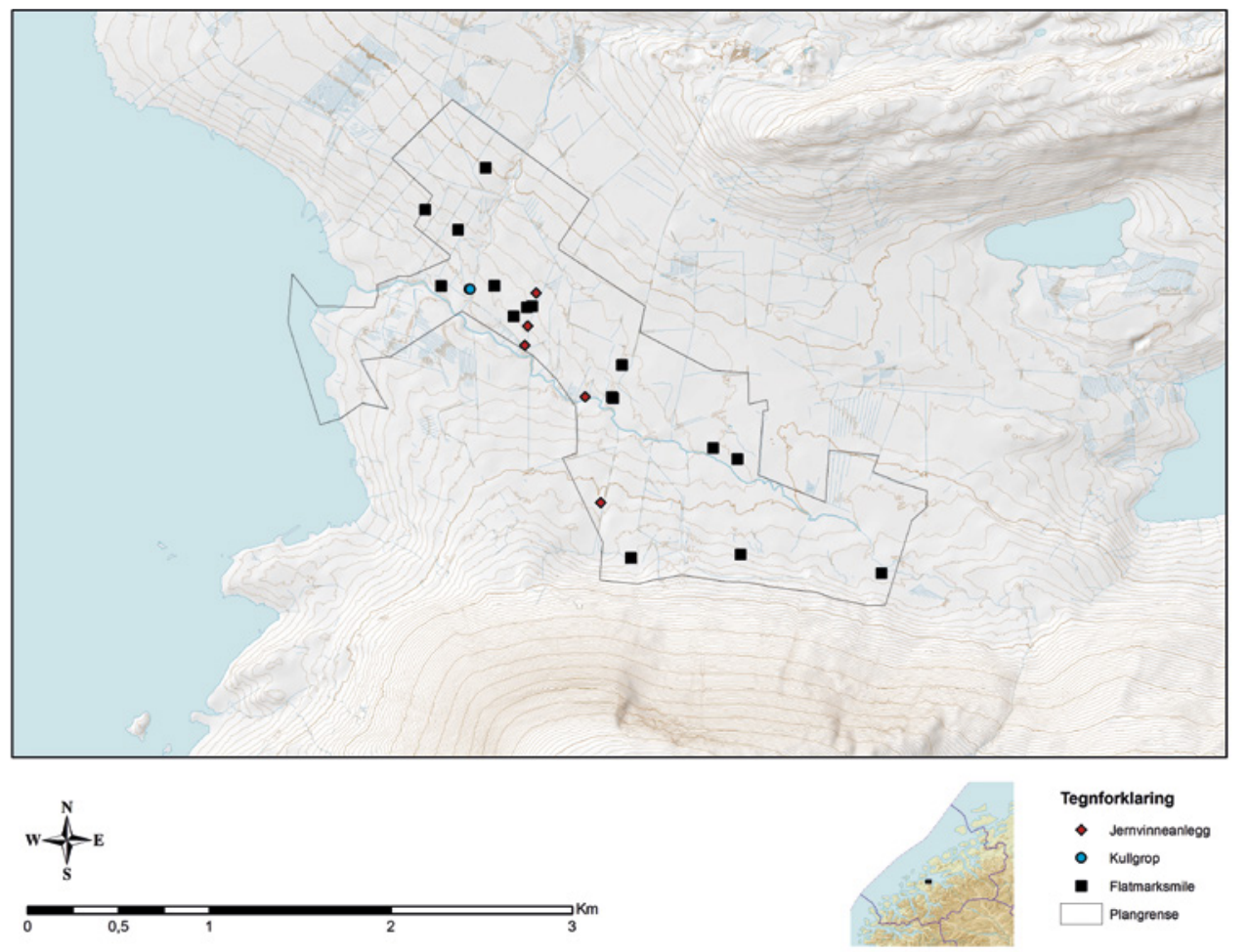

Figur 2. Oversikt over registrerte jern- og kullfremstillingsanlegg $i$ Vestnes i forbindelse med Møreaksen-prosjektet. Illustrasjon: Jo Sindre P. Eidshaug. Kartgrunnlag: Statens kartverk.

Nye jernvinneanlegg $i$ Vestnes

To nye jernvinneanlegg ble påvist langs en slak morenerygg like nord for Sinderhaugen, Lok 501 Sinderhaugen III og Lok 502 Sinderhaugen II. Lokalitetene er henholdsvis datert til 1020-1165 e.Kr. (Beta-419193, tabell 1) og 605-665 e.Kr. (Beta-419194, tabell 1). I tilknytning til begge anleggene ble det funnet mindre slagghauger, bestående av kull- og slaggblandede humøse løsmasser samt en god del hodestor, varmepåvirket stein. Ved den eldste av de to lokalitetene, Lok 502, ble det påvist et kullager som lå delvis eksponert i profilen til et traktorspor. Kullageret viste seg å være den tidligere registrerte kullforekomsten som ble omtalt ovenfor. Dateringsprøven Beta-419194 stammer fra kullageret.

De to øvrige jernfremstillingsanleggene, Lok 503 Lunheim I og Lok 510 Litlvidåna, har en annen type beliggenhet ved at de ligger på terrassekanter med slaggdeponi ned mot det tilknyttede elveleiet. Mens Lok 503 kunne dateres til 595-660 e.Kr. (Beta-419191, tabell 1), ble Lok 510 datert til 975-1030 e.Kr. (Beta-419196, tabell 1). I denne sammenheng er det vesentlig at det ved begge anleggene ble påvist kullforekomster tolket som kullagre.

\section{Nye kullforekomster $i$ Vestnes}

I utmarksområdet i Vestnes ble det som nevnt også registrert to kullgroper og seksten kullforekomster (Eidshaug 2016a:142-208, 267-276), se figur 2. De to kullgropene lå samlet, 
Tabell 1. Oversikt over C14-dateringer av jernvinneanlegg i Møre og Romsdal.

\begin{tabular}{|c|c|c|c|c|}
\hline Lokalitetsnavn & Datert materiale & Lab.ref. & Datering før nåtid (BP) & Kalibrert alder \\
\hline Lånemarka (180) & Ukjent & Beta-149153 & $2520 \pm 70$ & $820-410$ f.Kr. \\
\hline Lånemarka (180) & Ukjent & Beta-149154 & $2400 \pm 70$ & $780-370$ f.Kr. \\
\hline Øydegard & Bjørk, hassel, selje/vier/osp & Beta-365533 & $2390 \pm 30$ & 700-700/540-530/520-400 f.Kr. \\
\hline Kvernberget, lok. 8, K7/slagg & Kongle & TuA-6917 & $2275 \pm 30$ & $385-350$ f.kr. \\
\hline Kvernberget, lok. 8, K7/kulturlag & Bjørk, furu & T-19206 & $2160 \pm 70$ & $355-65$ f.Kr. \\
\hline Kvernberget, lok. 8, kullager 1 & Bjørk, hassel, furu & T-19205 & $2330 \pm 85$ & 410-260 f.kr. \\
\hline Kvernberget, lok. 8, kullager 2 & Bjørk, hassel & T-19204 & $1925 \pm 80$ & 10-205 e.Kr. \\
\hline Voll & Furu & T-13400 & $1925 \pm 80$ & 5-210 e.Kr. \\
\hline Sinderhaugen & Furu & T-9949 & $1915 \pm 45$ & 25-125 e.Kr. \\
\hline Sinderhaugen & Furu & T-9948 & $1880 \pm 80$ & $25-225$ e.Kr. \\
\hline Svartøken & Furu & T-16697 & $1630 \pm 65$ & 380-535 e.Kr. \\
\hline Svartløken & Bjørk, furu & T-16695 & $1525 \pm 75$ & 435-630 e.Kr. \\
\hline Svartøken & Furu & T-16696 & $1460 \pm 65$ & $550-655$ e.Kr. \\
\hline Fet-stølen & Ukjent & $\mathrm{T}-6204$ & $1390 \pm 80$ & 510-670 e.Kr. \\
\hline Lånemarka (423) & Ukjent & Beta-162393 & $1420 \pm 50$ & 550-680 e.Kr. \\
\hline Postvegen & Furu & T-16693 & $1460 \pm 35$ & $595-645$ e.Kr. \\
\hline Lok 503 Lunheim I & Furu & Beta-419191 & $1420 \pm 30$ & $595-660$ e.Kr. \\
\hline Lok 502 Sinderhaugen II & Furu & Beta-419194 & $1400 \pm 30$ & 605-665 e.Kr. \\
\hline Langrystene & Bjørk, furu & T-16694 & $1390 \pm 80$ & 610-685 e.Kr. \\
\hline Lyngstadgjerdet & Furu & T-16691 & $1340 \pm 70$ & 650-775 e.Kr. \\
\hline Gråsjøen & Furu & $\mathrm{T}-16692$ & $1295 \pm 35$ & 675-775 e.Kr. \\
\hline Berglomtjønnhaugen & Furu & Beta-359782 & $1110 \pm 30$ & 880-990 e.Kr. \\
\hline Gussiås & Furu & $\mathrm{T}-8234$ & $1010 \pm 80$ & 970-1110 e.Kr. \\
\hline Lok 510 Litlvidåna & Furu & Beta-419196 & $1030 \pm 30$ & 975-1030 e.Kr. \\
\hline Holm & Bjørk & Beta- 401510 & $1010 \pm 30$ & 985-1040/1110-1115 e.Kr. \\
\hline Holm & Furu & Beta-308020 & $1000 \pm 30$ & 990-1040/1100-1120/1140-1150 e.Kr. \\
\hline Holm & Bjørk & Beta-401511 & $830 \pm 30$ & 1160-1265 e.Kr. \\
\hline Smisethaugen & Bjørk, furu, vier/selje/osp & $\mathrm{T}-17456$ & $995 \pm 80$ & 990-1160 e.Kr. \\
\hline Myrset & Bjørk & Beta-385137 & $1000 \pm 30$ & $990-1145$ e.Kr. \\
\hline Nergulstølen & Furu & T-9950 & $975 \pm 50$ & 1010-1150 e.Kr. \\
\hline Lok 501 Sinderhaugen III & Furu & Beta-419193 & $940 \pm 30$ & 1020-1165 e.Kr. \\
\hline Gjeitnes & Furu & $\mathrm{T}-16062$ & $790 \pm 75$ & 1200-1290 e.Kr. \\
\hline
\end{tabular}




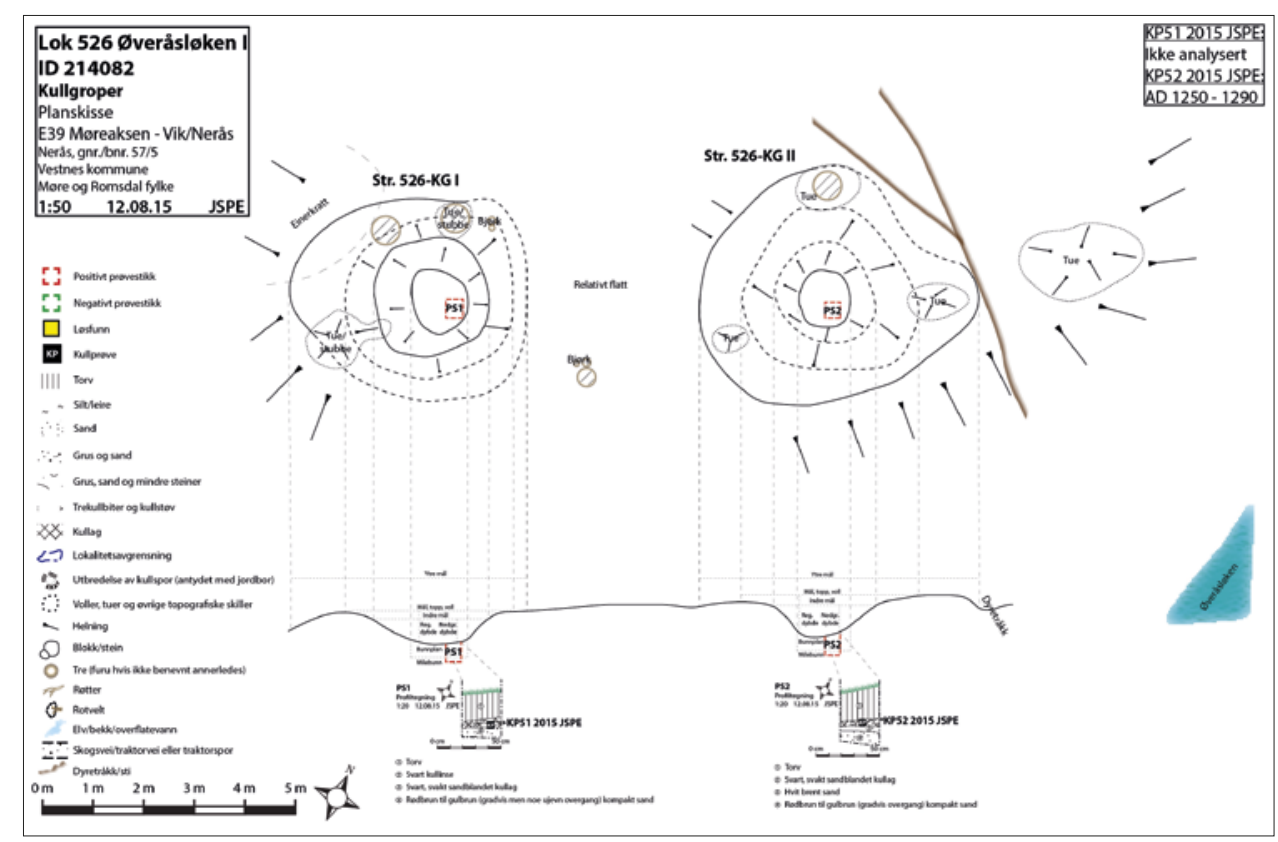

Figur 3. Plan- og profiltegninger av kullgroplokaliteten Lok 526 Øveråsløken I. Illustrasjon: Jo Sindre P. Eidshaug, Møre og Romsdal fylkeskommune.

og skilte seg ut visuelt i terrenget som tydelige groper med antydninger til voller (figur 3 ). Kullgropene var jevnstore, med en indre diameter på 3,3-3,5 m og et dybdemål på $0,65-$ 0,85 m (tabell 3). Dateringen av kullgroplokaliteten til 1250-1290 e.Kr. (Beta-419198, tabell 2), indikerer at kullgropene er yngre enn jernfremstillingsanleggene i Vestnes. I forhold til antallet registrerte jernvinneanlegg er dessuten antallet kullgroper mye lavere enn ventet.

Dateringene av de seksten kullforekomstene fordelte seg derimot innenfor perioden merovingertid-høymiddelalder, med hovedvekt på vikingtid-tidlig middelalder, se tabell 2. På grunn av sammenfallet i dateringene og de til dels massive lagene med kull som forekomstene bestod av, er det åpenbart at de er resultater av menneskelig aktivitet, ikke spor etter naturlige hendelser. Vår tolkning av kullforekomstene er at de representerer tidlige levninger etter kullfremstilling i flatmarksmiler.

Felles for kullforekomstene er at de består av homogene, ublandede kullag med maksimal dokumentert lagtykkelse på $8-50 \mathrm{~cm}$ (se figurene 4 og 5). Lagene var kun dekket av torv, og lå som oftest direkte over faste løsmasser, men av og til også over horisonter med eldre torvlag. De virker dermed å ligge på den eldre markoverflaten, og ikke i nedgravinger. I hovedsak ble de påvist $i$ et terreng som hadde en svak helling, eller som tilsynelatende var helt flatt, uten nødvendigvis å være markert i terrenget. Mens halvparten av dem var lokalisert på tørre drag, lå de andre i noe våtere og mer myrlendt terreng. Den antatte utbredelsen i plan varierer sterkt, fra mellom 1,3 m til omtrent $13 \mathrm{~m}$ i diameter. 
Tabell 2. Oversikt over C14-daterte kullfremstillingsanlegg fordelt på type. *) Usikkert anlegg. **) Vedartsbestemmelsen resulterte i 2 biter bjørk og 38 biter furu. ***) Vedartsbestemmelsen resulterte i 2 biter bjørk og 58 biter furu.

\begin{tabular}{|c|c|c|c|c|c|c|c|}
\hline Type & Lokalitetsnavn & $\begin{array}{l}\text { Datert } \\
\text { materiale }\end{array}$ & Lab.ref. & $\begin{array}{l}\text { Datering før } \\
\text { nåtid (BP) }\end{array}$ & $\begin{array}{l}\text { Kalibrert alder } \\
\text { (e.Kr.) }\end{array}$ & $\begin{array}{l}\text { Tillegg for } \\
\text { egenalder }\end{array}$ & $\begin{array}{l}\text { Justert } \\
\text { aldersintervall } \\
\text { (e.Kr.) }\end{array}$ \\
\hline \multirow{21}{*}{ 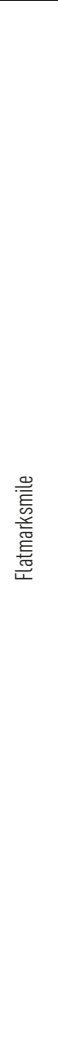 } & Åsgrova $1^{*}$ & Furu & Beta-415776 & $1470 \pm 30$ & $545-645$ & +100 & $545-745$ \\
\hline & Grepstad* & Furu & Beta-437158 & $1420 \pm 30$ & $595-660$ & +100 & $595-760$ \\
\hline & Lok 523 Ura IV & Furu & Beta- 428425 & $1340 \pm 30$ & $650-690 / 750-760$ & +100 & $650-860$ \\
\hline & Gjeitnes & Furu & $\mathrm{T}-16063$ & $1245 \pm 70$ & $680-885$ & +100 & $680-985$ \\
\hline & Lok 506 Lunheim II (506 KF I) & Furu & Beta-428451 & $1230 \pm 30$ & $685-885$ & +100 & $685-985$ \\
\hline & Lok 506 Lunheim II (506 KF II) & Furu & Beta- 428428 & $1190 \pm 30$ & $\begin{array}{l}725-740 / 770- \\
895 / 925-940\end{array}$ & +100 & $725-1040$ \\
\hline & Lok 516 Kvilet II* & Furu & Beta-428449 & $1190 \pm 30$ & $\begin{array}{l}725-740 / 770- \\
895 / 925-940\end{array}$ & +100 & $725-1040$ \\
\hline & Lok 511 Sinderhaugen VI & Bjørk** & Beta-428442 & $1150 \pm 30$ & $775-975$ & +50 & $775-1025$ \\
\hline & Lok 512 Uramyra & Furu & Beta- 428440 & $1130 \pm 30$ & $780-790 / 870-985$ & +100 & $780-1085$ \\
\hline & Lok 529 Øveråsløken IV & Furu & Beta-428446 & $1100 \pm 30$ & $885-1015$ & +100 & $885-1115$ \\
\hline & Lok 535 Øveråsløken V & Furu & Beta- 428435 & $1100 \pm 30$ & $885-1015$ & +100 & $885-1115$ \\
\hline & Gjermundnesåsane & Furu & T-19505 & $1080 \pm 45$ & $895-1015$ & +100 & $895-1115$ \\
\hline & Lok 504 Sinderhaugen IV & Furu & Beta-419192 & $1040 \pm 30$ & $970-1025$ & +100 & $970-1125$ \\
\hline & Lok 505 Sinderhaugen V & Furu & Beta- 428450 & $1030 \pm 30$ & $975-1030$ & +100 & $975-1130$ \\
\hline & Lok 508 Lunheim III & Furu & Beta-419195 & $980 \pm 30$ & 1015-1050/1080-1150 & +100 & $1015-1250$ \\
\hline & Lok 515 Kvilet I & Furu & Beta- 428425 & $950 \pm 30$ & $1020-1160$ & +100 & $1020-1260$ \\
\hline & Lok 532 Øveråsløken VI & Furu & Beta-428436 & $910 \pm 30$ & $1030-1210$ & +100 & $1030-1310$ \\
\hline & Lok 601 Neråssetra & Bjørk*** & Beta-437152 & $910 \pm 30$ & $1030-1210$ & +50 & $1030-1260$ \\
\hline & Lok 602 Øveråsløken VII & Furu & Beta-437153 & $870 \pm 30$ & $\begin{array}{l}1050-1085 / 1125- \\
1140 / 1150-1225\end{array}$ & +100 & $1050-1325$ \\
\hline & Lok 519 Flate I* & Furu & Beta-428437 & $790 \pm 30$ & $1210-1275$ & +100 & $1210-1375$ \\
\hline & Gjengstøen* & Furu & Beta-446796 & $560 \pm 30$ & $1310-1360 / 1385-1425$ & +100 & $1310-1525$ \\
\hline \multirow{12}{*}{ 을 } & Myrsethaugen & Furu & Beta-359781 & $820 \pm 30$ & $1160-1270$ & +100 & $1160-1370$ \\
\hline & Veøya, kullgrop 2 & Hassel & T-9966 & $725 \pm 85$ & $1230-1370$ & +50 & $1230-1420$ \\
\hline & Lok 526 Øveråsløken I (526-KG II) & Bjørk & Beta-419198 & $740 \pm 30$ & $1250-1290$ & +50 & $1250-1340$ \\
\hline & Vaagland Indre & Bjørk & Beta-446795 & $690 \pm 30$ & $1270-1305 / 1365-1385$ & +50 & $1270-1435$ \\
\hline & Veøya, kullgrop 5 & Hassel, alm & T-9969 & $575 \pm 70$ & $1290-1420$ & +50 & $1290-1490$ \\
\hline & Veøya, kullgrop 5 & Løvtre (diverse) & T-10215 & $575 \pm 65$ & $1295-1425$ & +50 & $1295-1475$ \\
\hline & Hennaelva & Bjørk & Beta-369267 & $560 \pm 30$ & $1310-1360 / 1390-1430$ & +50 & $1310-1480$ \\
\hline & Veøya, kullgrop 1 & Løvtre (diverse) & $\mathrm{T}-9965$ & $550 \pm 60$ & $1310-1430$ & +50 & $1310-1480$ \\
\hline & Veøya, kullgrop 3 & Løvtre (diverse) & T-9967 & $535 \pm 65$ & $1315-1435$ & +50 & $1315-1485$ \\
\hline & Sundet, lok 2* & Løvtre & T-13165 & $530 \pm 40$ & $1400-1435$ & +50 & $1400-1485$ \\
\hline & Veøya, kullgrop 4 & Hassel & $\mathrm{T}-9968$ & $485 \pm 45$ & $1410-1445$ & +50 & $1410-1495$ \\
\hline & Sundet, lok 5 & Furu & $\mathrm{T}-13166$ & $310 \pm 50$ & $1510-1655$ & +100 & $1510-1755$ \\
\hline
\end{tabular}




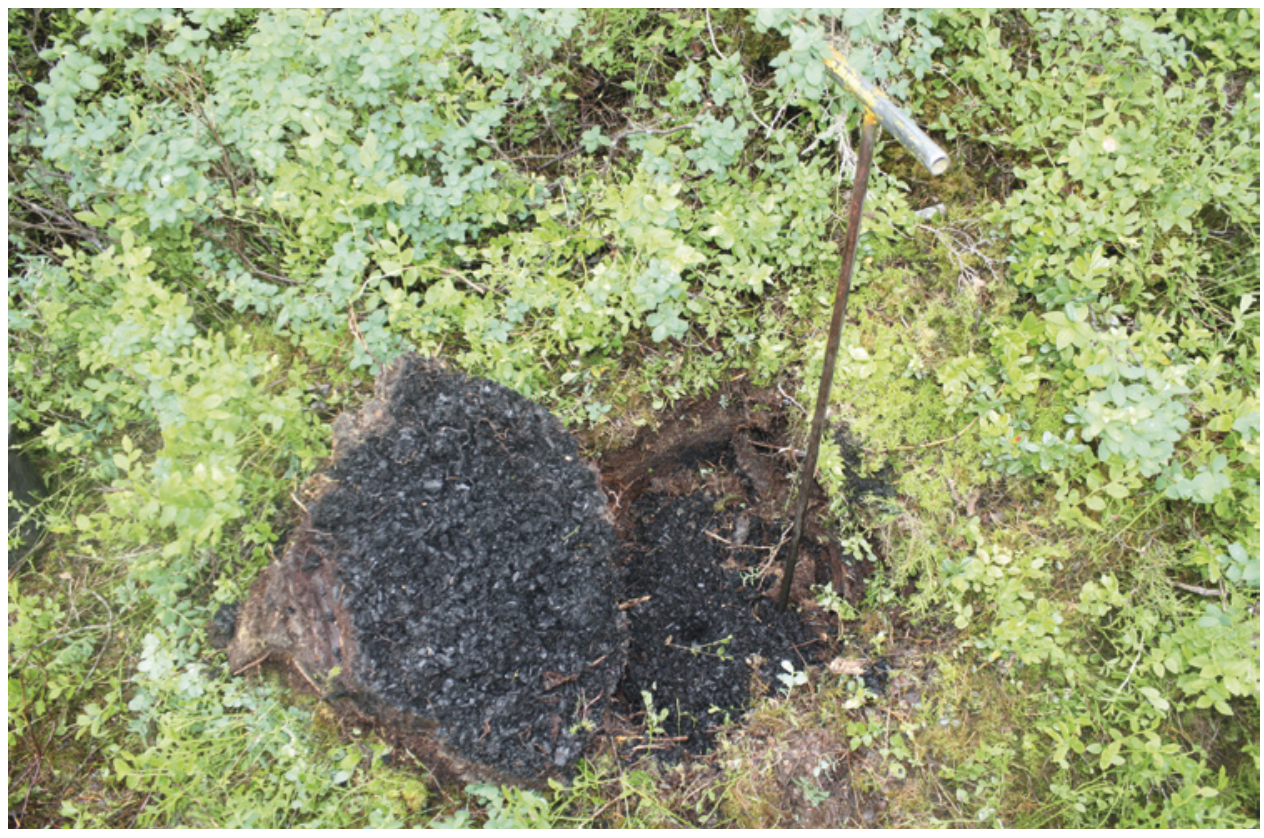

Figur 4. Massive kullag ble påvist $i$ prøvestikkene i kullforekomstene fra yngre jernalder og middelalder $i$ Vestnes. Bildet stammer fra et prøvestikk $i$ Lok 512 Uramyra. Foto: Jo Sindre P. Eidshaug, Møre og Romsdal fylkeskommune.

Figur 5. Et massivt, homogent kullag på ca. $30 \mathrm{~cm}$ ble påvist på Lok 508. Foto: Karen Ø. Oftedal, Møre og Romsdal fylkeskommune.

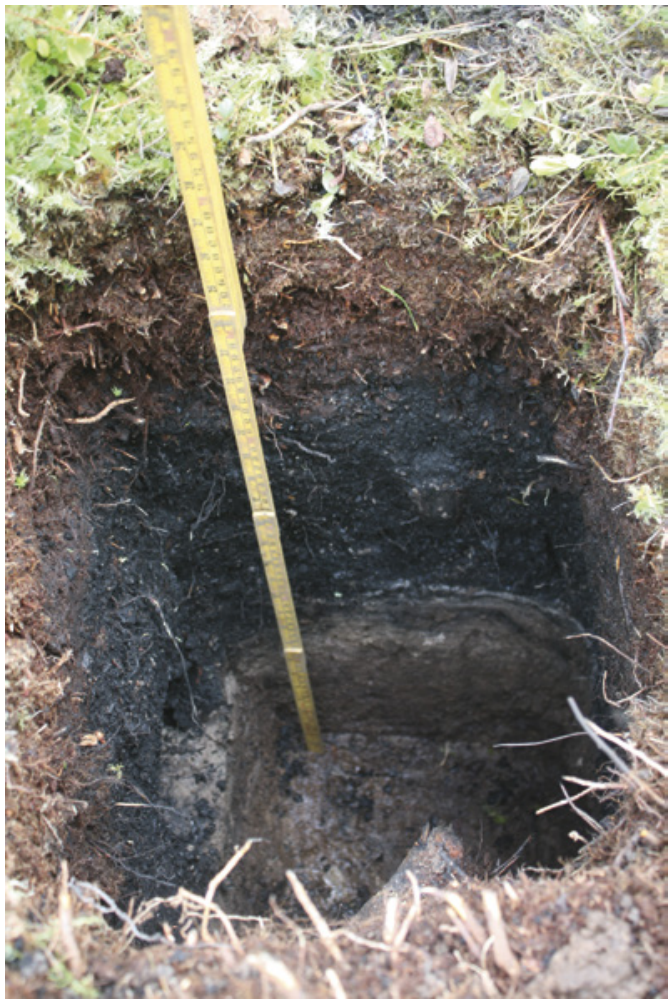


Fire kullforekomster, Lok 504 Sinderhaugen IV (figur 6), Lok 505 Sinderhaugen V (figur 7), Lok 511 Sinderhaugen VI og Lok 535 Øveråsløken V, ble påvist i nærheten av jernvinneanleggene Lok 501 og Lok 502. Disse er henholdsvis datert til 970-1025 e.Kr. (Beta419192, tabell 2), 975-1030 e.Kr. (Beta-428450, tabell 2), 775-975 e.Kr. (Beta-428442, tabell 2) og 885-1015 e.Kr. (Beta-428435, tabell 2). Lokalitetene er ikke synlige på markoverflaten, og ligger i et meget svakt hellende terreng eller på tilnærmet flat mark. Felles for dem alle er at de består av inntil 12-20 cm tykke, homogene kullag over fastmark. Noen sikker grunnbearbeiding ble ikke påvist, men det ble antydet at kullaget til Lok 505 kan ligge i en svak grop. Forekomstene er runde til ovale/avlange og har en målt maksimal diameter på 2,8-5,2 m.

Den eldste registrerte kullforekomsten har mange fellestrekk med de ovennevnte lokalitetene. Lok 523 Ura IV ble datert til 650-760 e.Kr. (Beta-428425, tabell 2) og ligger i et åpent, svakt hellende myrområde med et tynt torvdekke. Selve kullaget lå på faste, usorterte

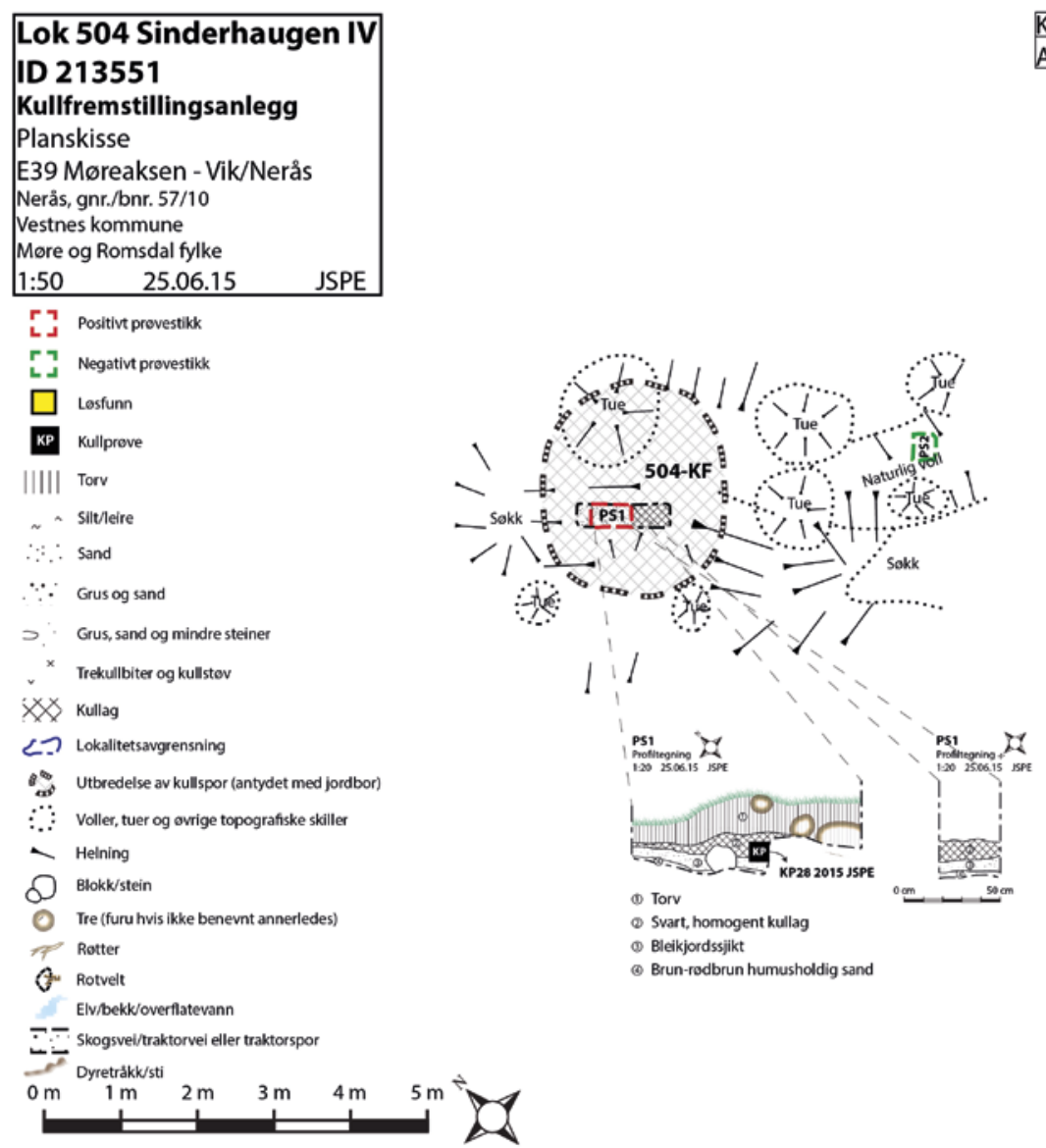

KP28 2015 JSPE:

AD $970-1025$

Figur 6. Plantegning av kullforekomsten Lok 504. Illustrasjon: Jo Sindre P. Eidshaug, Møre og Romsdal fylkeskommune. 


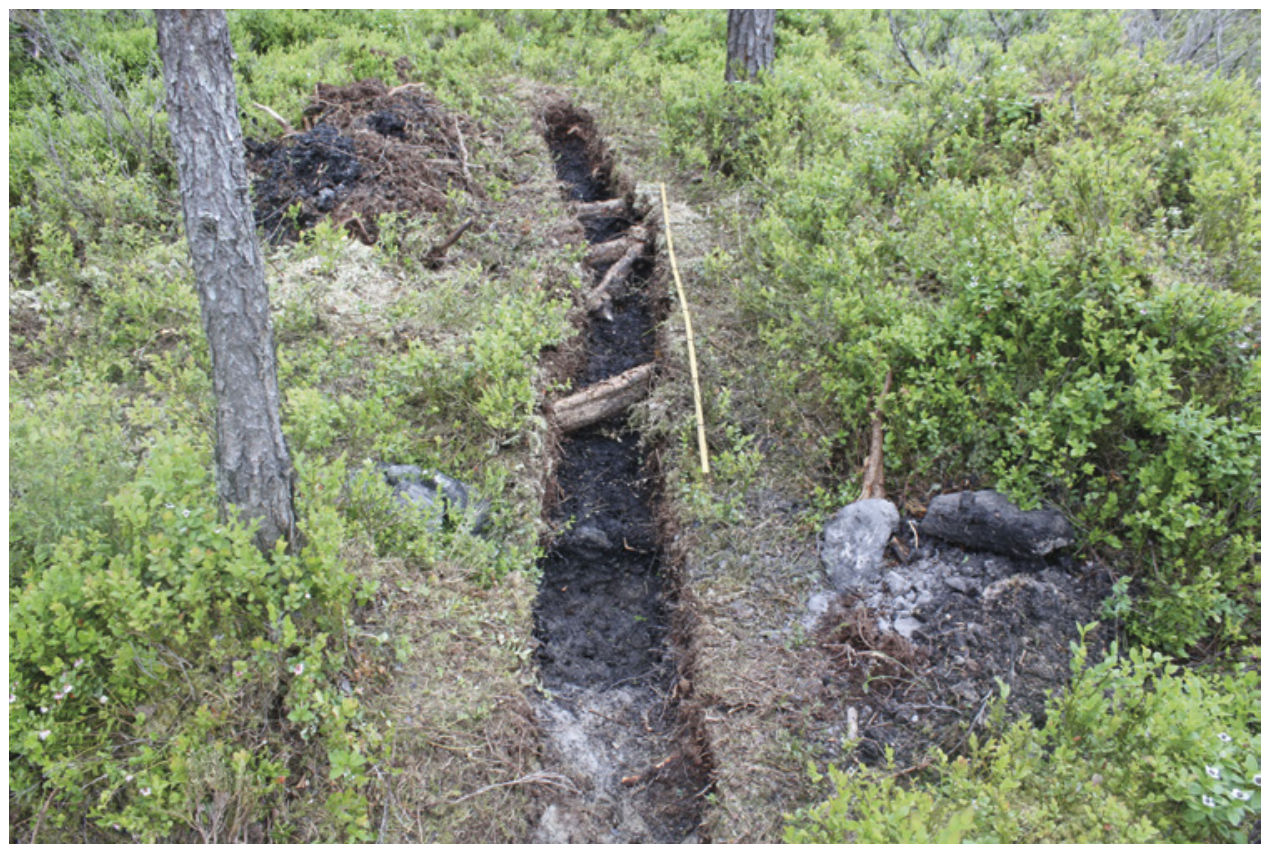

Figur 7. En smal avtorvingssjakt ble lagt over kullforekomsten Lok 505. Lokaliteten var ikke synlig på markoverflaten. Foto: Jo Sindre P. Eidshaug, Møre og Romsdal fylkeskommune.

løsmasser og målte inntil $18 \mathrm{~cm}$. Formen synes å være oval, og den maksimale diameter ble målt til 3,4 m.

Mektigere kullforekomster ble registrert på Lok 508 Lunheim III (figur 5), Lok 515 Kvilet I, Lok 532 Øveråsløken VI (figur 8), Lok 601 Neråssetra (figur 9) og Lok 602 Øveråsløken VII. Disse har noe yngre dateringer, henholdsvis 1015-1150 e.Kr. (Beta-419195, tabell 2), 1020-1160 e.Kr. (Beta-428425, tabell 2), 1030-1210 e.Kr. (Beta-428436, tabell 2), 10301210 e.Kr. (Beta-437152, tabell 2) og 1050-1225 e.Kr. (Beta-437153, tabell 2). Disse forekomstene har en maksimal diameter i plan på mellom 9,2 og 12,8 m, mens tykkelsen på selve kullagene ble målt til 22-50 cm. De er altså betydelig større enn de fem som er beskrevet ovenfor, og enkelte av dem skilte seg også noe ut på markoverflaten - som torvkledde (kull)hauger (se særlig figur 8). Likheten med de andre kullforekomstene er likevel slående i og med at de består av rene kullag, og de ser ut til å ligge på markoverflaten (minerogene løsmasser eller eldre torvlag) og ikke i groper.

I tabell 3 sammenfattes flere trekk ved de registrerte kullforekomstene i Vestnes. En tendens i materialet er at kullforekomstene blir større i volum (tykkere kullag og større planmål) i middelalderen. I likhet med øvrig materiale fra fylket opptrer kullgropene først i høymiddelalderen. 


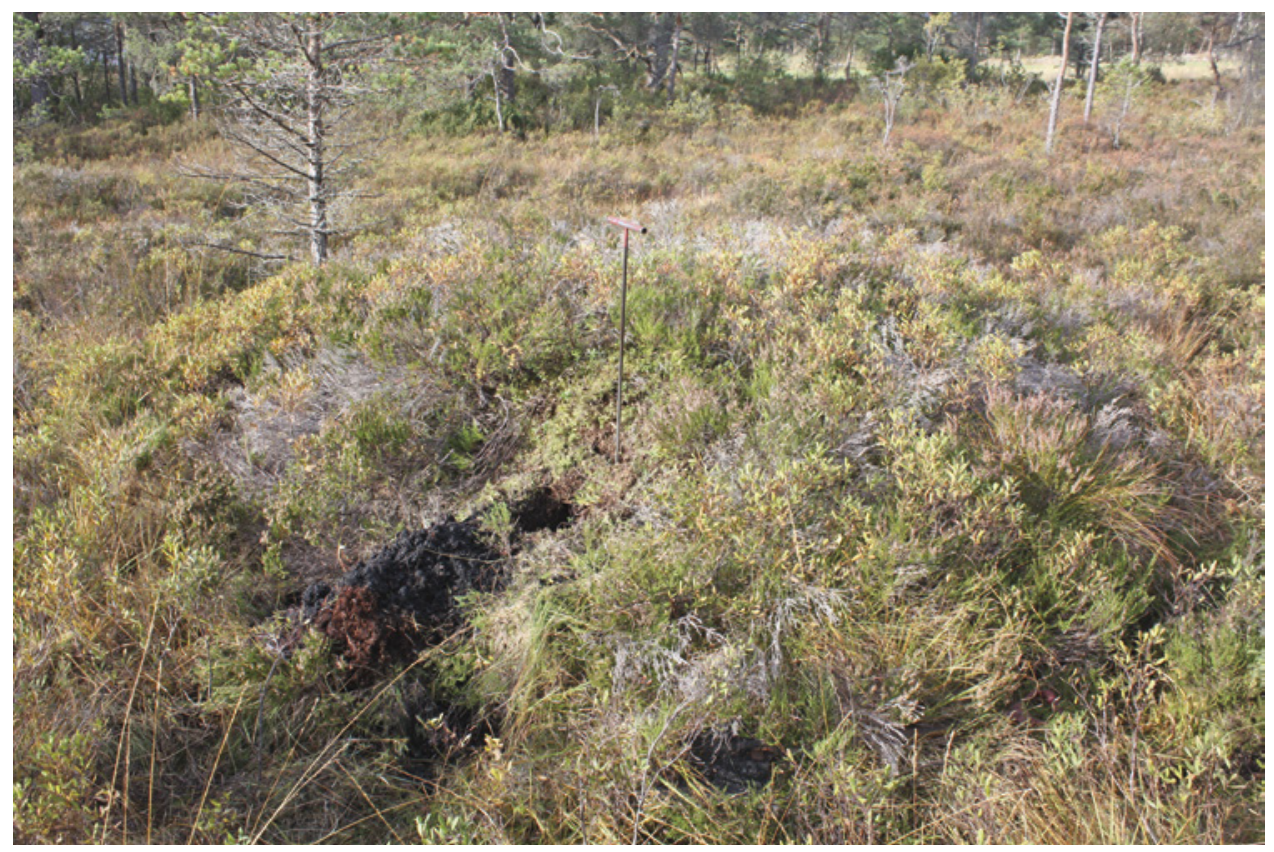

Figur 8. Lok 532 Øveråsløken VI var blant de få kullforekomstene som hadde en relativt tydelig markering på overflaten. Dybden på kullaget $i$ utkanten av haugen målte hele $50 \mathrm{~cm}$. Foto: Jo Sindre P. Eidshaug, Møre og Romsdal fylkeskommune.

\section{Metodiske utfordringer}

I diskusjonen om kullforekomstene ligger det en vesentlig innvending mot bastante tolkninger i det faktum at ingen av dem er blitt undersøkt gjennom arkeologiske utgravninger. Vi mangler dermed kunnskap om hvordan kulturminnene ser ut i plan på forskjellige horisontale nivåer, og vi savner en fullstendig profil gjennom kulturminnet som kan synliggjøre oppbyggingen og lagsammensetningene. I tillegg har vi ikke kunnskap om grunnbearbeiding eller eventuell teknologi. Vi erkjenner derfor at vi på det nåværende tidspunkt mangler detaljert kunnskap om kullforekomstene. Basert på det foreliggende datamaterialet ønsker vi like fullt å etablere et godt kunnskapsgrunnlag og utvikle hypoteser for eventuelle videre undersøkelser. Hvis en utgravning skal kunne gi oss kunnskap om en ny kategori kulturminner, må vi under registreringsfasen evne å erkjenne potensielle nye kulturminnetyper.

I vår sammenheng blir det derfor viktig å skille mellom funksjonstolkningen og detaljkunnskapsnivået som angår milekonstruksjon og kullbrenningsteknikk. Potensialene for å skape kunnskap om det sistnevnte nivået er som antydet begrenset ved enkle registreringer. For eksempel har utgravninger i Gråfjellområdet vist at et stort antall av de registrerte kullgropene var kvadratiske snarere enn rektangulære, en variasjon som tilskrives vedstablingsteknikk (Rundberget 2013:145). Bernt Rundberget (2013:146) tolker likevel både disse variasjonene og forskjeller i størrelse som uttrykk for ulike behov, ikke som et resultat av ulike kullbrennermetoder. Et viktig poeng er at funksjonstolkningen som kullgrop fra registreringen står ved lag, mens detaljkunnskapen om dem har økt. 


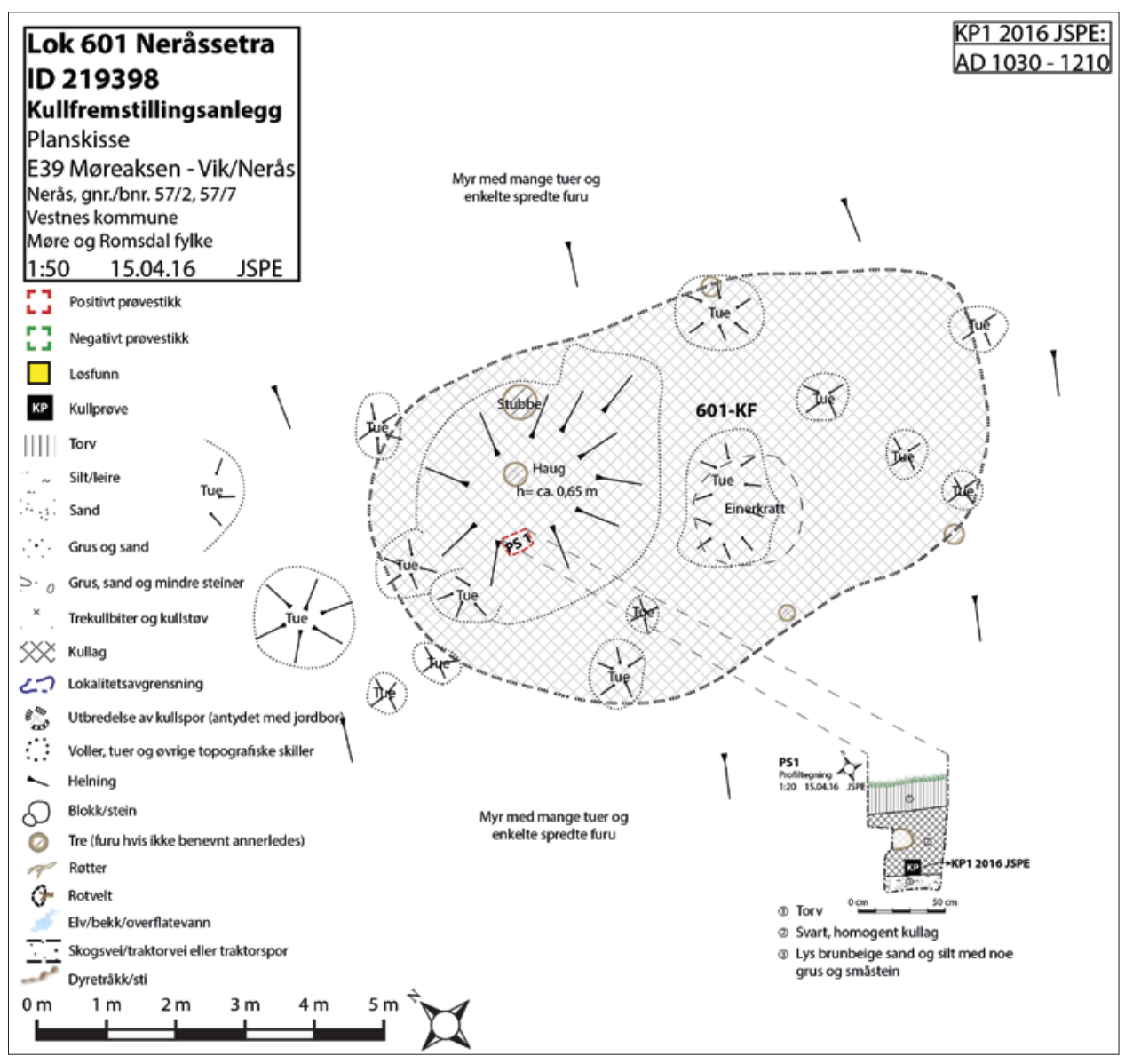

Figur 9. Plantegning av kullforekomsten Lok 601. Illustrasjon: Jo Sindre P. Eidshaug, Møre og Romsdal fylkeskommune.

Det å tolke strukturer eller lag uten å grave i dem er utfordrende, men metodene som ble anvendt under Møreaksen-prosjektet, hadde som formål å bidra til en tolkning av kulturminnetypen - spesielt som følge av at det etter hvert dukket opp flere forekomster av kull som ikke hadde noen åpenbar funksjon. Under påvisningen av noen av de første kullforekomstene ble det derfor i tillegg til prøvestikking lagt smale manuelle sjakter over kullagene (inntil ca. $5 \mathrm{~m}$, se figur 7). Siden ble inngrepene begrenset til prøvestikk som ble forsøkt satt der lagene syntes å være tykkest, mens øvrige prøvestikk og/eller jordboring ble benyttet til avgrensning av kullforekomstene. Ettersom avgrensningsmetoden kan være noe problematisk når det gjelder å skille mellom adskilte aktivitetsspor og lag som har en direkte sammenheng med en eventuell struktur, foreligger det et usikkerhetsmoment rundt strukturenes horisontale dimensjoner.

En av utfordringene vi dessuten må vurdere, er prøvekonteksten (Loftsgarden mfl. 2013). I tilfeller der prøvematerialet er blitt hentet ut fra lag som kun observeres i mindre prøve- 
Tabell 3. Sammenfatning av kjennetegn ved de nye kullforekomstene i Vestnes.

\begin{tabular}{|c|c|c|c|c|c|c|}
\hline Lokalitet & Terreng & Lagbeskrivelse & Form i plan & $\begin{array}{l}\text { Mål } \\
\text { (m) }\end{array}$ & $\begin{array}{l}\text { Lagtykkelse } \\
\text { (cm) }\end{array}$ & Kommentar \\
\hline Lok 504 & Meget svak helning & Homogent kullag & Sirkulær & $2,8 \times 2,7$ & 15 & \\
\hline Lok 505 & Flatt & Homogent kullag & Oval, irregulær & $4,0 \times 3,5$ & 20 & Mulig grunn grop \\
\hline $\begin{array}{l}\text { Lok } 506 \\
\text { (KF I) }\end{array}$ & Svak helning & Homogent kullag & Avlang, irregulær & $8,5 \times 3,5$ & 14 & \\
\hline $\begin{array}{l}\text { Lok } 506 \\
\text { (KF II) }\end{array}$ & Flatt, men ulendt & Homogent kullag & $\begin{array}{l}\text { Rektangulær, } \\
\text { avrundet }\end{array}$ & $2,9 \times 1,2$ & 12 & $\begin{array}{l}\text { Ligger i en forsenkning som } \\
\text { danner vegger i tre av retningene } \\
\text { Plan med bakknivå mot øst }\end{array}$ \\
\hline Lok 508 & Flatt & Homogent kullag & Avlang, irregulær & $8,2 \times 4,0$ & 30 & \\
\hline Lok 511 & Meget svak helning & Homogent kullag & Avlang, irregulær & $4,5 \times 2,8$ & 18 & \\
\hline Lok512 & Meget svak helning & Homogent kullag & Eggformet, irregulær & $14,0 \times 9,0$ & 20 & $\begin{array}{l}\text { Kullkonsentrasjonen er mindre } \\
\text { enn oppgitte mål }\end{array}$ \\
\hline Lok 515 & Svak helning & Homogent kullag & Oval, irregulær & $11,0 \times 7,0$ & 22 & \\
\hline Lok 516 & Svak helning & Homogent kullag & Eggformet, irregulær & $1,3 \times 1,2$ & 8 & Meget begrenset omfang \\
\hline Lok 519 & Helning & $\begin{array}{l}\text { Homogent kullag i ps1, } \\
\text { kullblandet sand i ps2 }\end{array}$ & Oval & $11,0 \times 6,0$ & 12 & $\begin{array}{l}\text { Usikker tolkning, skiller seg } \\
\text { noe ut }\end{array}$ \\
\hline Lok 523 & Svak helning & Homogent kullag & Oval & $3,4 \times 2,9$ & 18 & \\
\hline $\begin{array}{l}\text { Lok } 526 \\
\text { (KG I) }\end{array}$ & Flatt & $\begin{array}{l}\text { Homogent kullag over svakt } \\
\text { sandblandet kullag }\end{array}$ & Rundoval & $4,7 \times 4,0$ & 8 & $\begin{array}{l}\text { Kullgrop. Indre diameter: } 3,3 \mathrm{~m} \text {, } \\
\text { dybde: 0,65 m }\end{array}$ \\
\hline $\begin{array}{l}\text { Lok } 526 \\
\text { (KG II) }\end{array}$ & Flatt & Homogent kullag & Rundoval & $5,5 \times 4,6$ & 5 & $\begin{array}{l}\text { Kullgrop. Indre diameter: } 3,5 \mathrm{~m} \text {, } \\
\text { dybde: } 0,85 \mathrm{~m}\end{array}$ \\
\hline Lok 529 & Flatt & Homogent kullag & Oval & $6,4 \times 4,5$ & 18 & Skadet av groft \\
\hline Lok 532 & Svak helning & Homogent kullag & Avlang, irregulær & $11,7 \times 6,2$ & 50 & \\
\hline Lok 535 & Svak helning & Homogent kullag & Eggformet & $5,2 \times 4,8$ & 12 & \\
\hline Lok 601 & Svak helning & Homogent kullag & Oval-avlang & $9,2 \times 5,5$ & 40 & \\
\hline Lok 602 & Meget svak helning & Homogent kullag & Oval & $12,8 \times 10,8$ & 50 & \\
\hline
\end{tabular}

stikk, savner man gjerne tilstrekkelig stratigrafisk kontroll (Larsen 2009:212-215; Loftsgarden mfl. 2013:63-66). Det åpner for at det er vanskelig å relatere prøven til en spesifikk fase eller aktivitet, og man kan ikke utelukke at det finnes eldre eller yngre faser. Når det gjelder kullforekomstene i Vestnes, ble prøvene tatt ut fra bunnen av massive kullag, helst der de var tykkest. Vi vil derfor hevde at prøvene stammer fra en relativt sikker funksjonsbestemmende kontekst, og det tilfredsstiller forutsetningene for diskusjonen.

Registreringsmetodene ga oss punktvis innsyn i stratigrafisk oppbygning, grunnlag for beskrivelse av lagenes bestanddeler og tykkelse, mulighet til å ta ut dateringsprøve samt en indikasjon på lagets utbredelse i plan. Ettersom det i datagrunnlaget ble funnet visse mønster - lagbeskrivelse, datering, beliggenhet i terrenget, beliggenhet i nærheten av andre samtidige kulturminner - vil vi hevde at vi også har grunnlag for å foreta en tolkning. Slik det er vanlig i arkeologien, støttes en slik tolkning av analogier. 
På et mer generelt nivå må vi til slutt advare om potensielle feilkilder når det gjelder dateringene (jf. Loftsgarden mfl. 2013). En velkjent problemstilling omhandler egenalderen til det daterte materialet, som i flere av våre tilfeller er furu. Undersøkelser av furustokker fra kullgroper i Gråfjellområdet har vist at egenalderen kan være opp mot 200 år. Gjennomsnittet til det undersøkte materialet lå likevel på ca. 100 år (Rundberget 2007:316). For å ta høyde for feilmarginen kan man justere ned den potensielt laveste alderen til C14-dateringer av furuprøver med omtrent 100 år (Stenvik 2015b:223). Det er imidlertid viktig å tolke det i retning av økt usikkerhet, siden vi ikke vet fra hvilken del av trestammen prøven stammer.

\section{Flatmarksmiler, kullagre, tjæremiler eller noe annet?}

I det følgende vil vi argumentere for at kullforekomstene representerer levningene etter en hittil lite omtalt kulturminnetype: flatmarksmiler fra yngre jernalder og middelalder. Ettersom en slik påstand krever kvalifikasjoner, skal vi drøfte mulige innvendinger og alternative tolkninger - slike som tjæremiler, røsteplasser, bålplasser og kullagre.

Det fremste argumentet for at disse levningene er spor etter kullfremstilling, er at lagene består av rent trekull. Kullforekomstenes struktur og dimensjoner er viktige for å utelukke at de er levninger etter bålplasser, brannrydninger eller mer tilfeldige brenninger. Renheten i kullagene, ensartetheten i trevirket og det faktum at lagene til tider er voldsomt massive, synes å peke i retning av at kullet må tolkes som funksjonsbestemmende for disse kulturminnene.

Vedartsbestemmelsen viser at furu nesten utelukkende er blitt benyttet (tabell 2). Valget av trevirke virker intensjonelt, som et valg tatt med sikte på en spesifikk aktivitet. Det er også påfallende at det er furu som er påvist i slagghaugene og kullforekomstene like ved jernvinneanleggene (tabell 1). Forutsettes det at anvendt vedart i kullfremstillingsprosessen følger lokal tilgjengelighet (jf. Loftsgarden 2015:149), stemmer anvendelsen av furu med topografien i området.

En alternativ tolkning av lokalitetene som tidlige tjæremiler svekkes av at det ikke ble påvist ufullstendig forkullet ved. Det er et vanlig kjennetegn for tjæremiler, også innenfor planområdet $\mathrm{i}$ Vestnes, der det ble påvist fem tjæremiler. Tjære ble utvunnet ved at kjerneved av furu varmes opp og forbrennes utenfra og innover - en prosess som dermed er vesensforskjellig fra kullfremstilling, der reduksjonen foregår ved at trevirket brennes innenfra og utover (Bloch-Nakkerud 1987:97; Dahle 2007:253; Farbregd 1989:10; Gundersen og Wenn 2011:242).

Kullforekomstenes størrelse og struktur skiller seg også betydelig fra kjente tjæremiler i området. Til tross for at det råder en viss usikkerhet knyttet til strukturenes faktiske dimensjoner, virker kullforekomstene jevnt over å være mindre enn tjæremilene som ble registrert i forbindelse med prosjektet. Fire av de fem tjæremilene hadde dessuten kraftige voller og oppsamlingsrenner, samt markert stratigrafi i vollene. Særlig vekslet lag med kullblandede sandlag og rene sandlag, antakelig som følge av gjentatte brenninger, der ren sand er blitt benyttet til bearbeiding av milebunnen (jf. Gundersen og Wenn 2011:259). Tjæremilene i området var også yngre enn kullforekomstene, og antas å kunne dateres til overgangen mellom senmiddelalder og nyere tid på bakgrunn av tre radiologiske dateringer av bark eller løvtre (for diskusjon, se Eidshaug 2016a:210-213). 
Sammenhengen med andre kulturminner i området - den kulturhistoriske konteksten er dessuten viktig for å forstå kullforekomstene. Lokaliseringen i et område hvor det også ble påvist flere jernvinneanlegg, antyder et behov for kull - trolig både i sammenheng med selve jernfremstillingsprosessen i sjaktovnene og i forbindelse med smievirksomhet. Denne sammenhengen styrkes av dateringene. Spredningen fra slutten av merovingertid og frem mot høymiddelalderen faller sammen med alderen på de nyregistrerte jernfremstillingsanleggene i Vestnes. Et sentralt argument er at tilsvarende kullforekomster også opptrer like ved jernvinneanleggene. Det gjenstår for øvrig å fastslå hvorvidt dette er rene kullagre ettersom de ikke er undersøkt, eller om også dette kullet ble produsert på stedet, og man senere etablerte ovner like ved.

Det finnes i tillegg innvendinger mot at kullforekomstene som ble registrert i Vestnes, kun er lagringsplasser for kull. Selv om de naturlige grunnforholdene ofte gjorde det vanskelig å bedømme, fantes det mulige antydninger til brent sand under enkelte av kullagene. Det foreligger videre ingen teknologisk begrunnet årsak til at man skal ha importert kull, siden fremstilling av jern forutsetter innsikt $i$ en mye mer komplisert prosess enn kullfremstilling. Det virker heller ikke sannsynlig at kullet skal ha blitt importert fra andre steder i regionen, ettersom vi ikke finner spor etter kullproduksjon fra samme periode som kullforekomstene (jf. tabell 2). Kullgropene i Møre og Romsdal er både få og yngre enn kullforekomstene. På landsbasis har vi også få sikre spor etter kullfremstilling i grop fra før 800 e.Kr., og en stabil høy produksjon nås først på 900-tallet (Larsen 2004:153-154; Loftsgarden 2015:150). At ni av de trettitre registrerte kullforekomstene i Møre og Romsdal kan ha en tidligere datering enn 900-tallet, burde derfor snarere antyde at de er levninger etter lokalprodusert kull enn importert kull.

En tolkning av anleggene som røsteplasser vil vi utelukke med bakgrunn $i$ at det under registreringen i Vestnes aktivt ble anvendt relativt kraftige magneter til å undersøke jordsmonnet i omtrent alle prøvestikk - uten at magnetisk malm ble påvist.

Etter vår mening bør derfor kullforekomstene knyttes til fremstilling av kull. Visuelt skiller de seg fra kullgroper og kullmiler som er kjent fra senere perioder. Enkelte anlegg har tendenser til svake gropdannelser, men disse fremstår enten som naturlige eller uavklarte. De skiller seg uansett klart fra de to kullgropene som er registrert innenfor planområdet. Det er heller ingen voller eller grøfter, slik man gjerne finner ved flatmarksmilene fra nyere tid, knyttet til fremveksten av bergverk. Vår oppfatning er derfor at kullforekomstene bør tolkes som levninger etter flatmarksmiler fra yngre jernalder og middelalder.

\section{Kullbrenningen i videre perspektiv}

Behovet for kull kan føres tilbake til bronsealderen, men vi vet lite om i hvilke former kullfremstillingen foregikk i periodene før yngre jernalder (Rundberget 2013:62-63). Tidligere er det også blitt stilt spørsmål om den eldre produksjonen av kull nødvendigvis har foregått i groper (Larsen 2003:92). Lars Erik Narmo (1996b:28, 1997:180) har hevdet at det er logisk at man har kjent til flatmarksmileprinsippet - forkulling over bakkenivå - når man brente kull i groper. Årsaken til at man foretrakk brenning i grop, kan trolig skyldes at man fikk en jevnere forkulling av trevirket. Av flatmarksmiletypene, liggemiler og reismiler er liggemilen den eldste kjente typen i Norge, og ettersom den også prinsipielt og konstruksjonsmessig ligner mest på kullgropen, har man antatt at det er en direkte sammenheng mellom 
disse to metodene (Narmo 1997:180; Rundberget 2013:57). Derimot har man antatt at reismilene ikke går tilbake lengre enn 1600-tallet i Norge, og at denne teknikken bør sees som en import fra Sverige og Tyskland i sammenheng med etableringen av bergverksdriften (f.eks. Bloch-Nakkerud 1987:76-77; Narmo 1996a:43-46; 1996b:27; 1997:180; Rundberget 2013:57-58).

I Trøndelag er det funnet relativt få kullgroper i forhold til hva man skulle forvente om man bruker Østlandet som sammenligningsgrunnlag. Aller flest kullgroper er blitt påvist i nærheten av Trondheim. Disse er relativt små og tolkes som produksjonssteder for smikull (Berge 2009), tilsvarende det vi ser på Veøya. Lars Stenvik (2015a:92-93) påpeker således at metodene man brukte for å fremstille kull i yngre jernalder og middelalder i Trøndelag, representerer et kunnskapshull i jernvinneforskningen. Han hevder videre at det foreligger indikasjoner på at man må ha produsert kullet over bakkenivå snarere enn i gropene som er vanlige på Østlandet. Mulighetene for det støttes også opp ved funn av flere senmiddelalderske flatmarksmiler (Berge 2011a, 2011b).

En flatmarksmile som trolig kan dateres til senmiddelalderen, er også blitt undersøkt på Julsrud i nærheten av Minnesund (Melvold mfl. 2010:42-43; Storrusten 2012). Fra forskjellige steder i Sverige, hvor et betydelig antall flatmarksmiler er blitt utgravd, har man dessuten belegg for varianter av slike tilbake til begynnelsen av middelalderen (Lönnquist

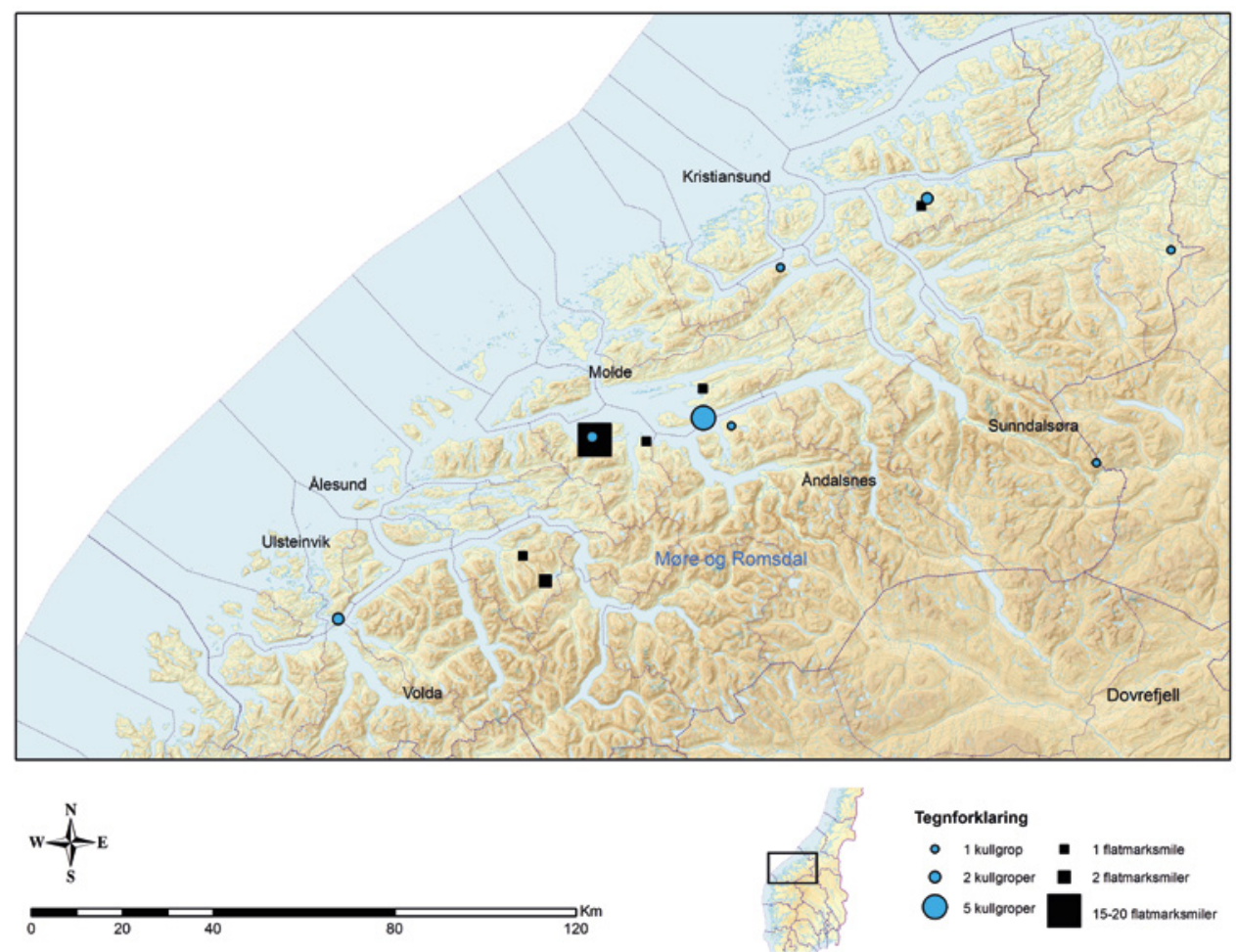

Figur 10. Geografisk spredning av kullfremstillingsanlegg fordelt på type.

Illustrasjon: Jo Sindre P. Eidshaug. Kartgrunnlag: Statens kartverk. 
og Welinder 2011). Disse undersøkelsene har også medført at man i dag ikke lenger kan fastslå om reismilene eller liggemilene er eldst av flatmarksmilene. I lys av synet på reismilene i Norge er det interessant å notere at man i Sverige har kunnet avvise en tidligere «etablert sannhet» om at reismileteknikken først ble innført på 1600-tallet med den vallonske innvandringen (Lönnquist og Welinder 2011:207, med henvisninger). En kategorisk avvisning av en eldre tradisjon med produksjon av kull i flatmarksmiler er derfor urimelig.

I Møre og Romsdal er det blitt funnet særdeles få kullgroper (figur 10), også sammenlignet med Trøndelag. De synes først å opptre fra høymiddelalderen (1200-tallet), og flere er blitt datert til senmiddelalderen (tabell 2). Produksjonen av kull i grop sammenfaller dermed med en periode vi på fylkesbasis foreløpig ikke har belegg for at det har forekommet jernfremstilling (tabell 1), med et mulig unntak for kullgropa på Myrsethaugen fra omkring 1200 e.Kr. Mangelen på kronologisk overlapping og fraværet av kullgroper i nærheten av jernvinneanlegg tyder på at de kjente kullgropene trolig snarere bør tolkes i sammenheng med produksjon av smikull. Denne tendensen er illustrert i tabell 4, som viser hvilke av de daterte kullfremstillingsanleggene i Møre og Romsdal som har påvist samtidige jernvinneanlegg. Tallene i parentes inkluderer anlegg hvor differansen mellom dateringsintervallene er under 100 år, som et grep for å ta høyde for at ett av de to prøveresultatene som sammenlignes, kan stamme fra furu med høy egenalder. Selv om representativiteten til materialet kan bestrides, aner vi i tillegg til det kronologiske skillet også et formålsskille mellom flatmarksmiler og kullgroper i tabell 4. Produksjonen av kull i flatmarksmiler bør trolig sees i sammenheng med jernvinna.

Ser vi på materialet fra Vestnes isolert (tabell 4, figur 11, se også figur 2), er det blitt påvist samtidige jernvinneanlegg innenfor en radius på mellom $100 \mathrm{~m} \mathrm{og} 2,4 \mathrm{~km}$ til samtlige av de registrerte flatmarksmilene. Spesielt mange miler overlapper med de to yngste jernvinneanleggene (Lok 501 og Lok 510). Innenfor lokalitetsgrensen til tre av de fire jernvinneanleggene ble det også påvist kullforekomster som ble tolket som kullagre.

Til tross for at tabell 4 også viser at datamaterialet foreløpig er spedt, og at tolkningsrommet derfor er stort, danner dette sammenfallet i tid og rom mellom kull- og jernfremstilling i Vestnes en viktig kulturhistorisk kontekst. Ettersom det indikerer at kullfyring i sjaktovnene må ha blitt introdusert på et relativt tidlig stadium, vil en slik tolkning dessuten kunne ha relativt vidtfavnende konsekvenser for hvordan vi forstår utviklingen av jernvinna i Møre og Romsdal.

Dateringene av flere flatmarksmiler og kullagre tilbake til 600-700-tallet bør for øvrig være oppsiktsvekkende ut fra kunnskapsstatusen til kullbrenningen på landsbasis. Mens vi kjenner til kullgroper fra førromersk jernalder på Hemmestad i Nord-Norge, foreligger det generelt få dateringer av kullgroper til perioden før vikingtid (Rundberget 2013:62-63, se også Larsen 2004:153-154). Om dateringsspennet tabell 2 viser, er representativt for kullbrennertradisjonen i Møre og Romsdal, er opptakten til denne tidlig i forhold til den langt mer omfattende kullgropstradisjonen på Østlandet. Dessuten er den eldste flatmarksmilen neppe blitt påvist ennå - kun fremtidige undersøkelser vil kunne utdype dette bildet.

\section{Avslutning}

Mangelen på spor etter kullfremstillingsanlegg fra vikingtid og tidlig middelalder i Møre og Romsdal har representert et kunnskapshull i forståelsen av den regionale utviklingen av 
Tabell 4. Oversikten viser hvilke flatmarksmiler og kullgroper som har påviste samtidige jernvinneanlegg i ncerområdet. Tabellen antyder en sammenheng mellom flatmarksmilene og jernfremstillingsanleggene $i$ Vestnes, mens kullgropene snarere bør kobles til smieaktivitet. Tall i parentes inkluderer anlegg hvor differansen mellom dateringsintervallene er under 100 år.

\begin{tabular}{|c|c|c|c|c|}
\hline Type & Lokalitetsnavn & Kalibrert alder & Samtidige jernvinne-anlegg & Avstand (m) \\
\hline \multirow{21}{*}{ 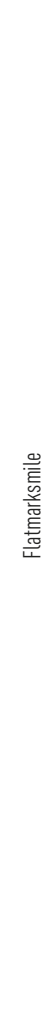 } & Åsgrova $1^{*}$ & 545-645 e.Kr. & 1 & 1000 \\
\hline & Grepstad* & $595-660$ e.Kr. & - & - \\
\hline & Lok 523 Ura IV & 650-690/750-760 e.Kr. & 2 & $1200-1850$ \\
\hline & Gjeitnes & 680-885 e.Kr. & - & - \\
\hline & Lok 506 Lunheim II (506 KF I) & 685-885 e.Kr. & (2) & $150-720$ \\
\hline & Lok 506 Lunheim II (506 KF II) & 725-740/770-895/925-940 e.Kr. & (3) & $150-720$ \\
\hline & Lok 516 Kvilet II* & 725-740/770-895/925-940 e.Kr. & (3) & $690-1300$ \\
\hline & Lok 511 Sinderhaugen VI & 775-975 e.Kr. & $1(2)$ & $100-1150$ \\
\hline & Lok 512 Uramyra & 780-790/870-985 e.Kr. & 1 & 345 \\
\hline & Lok 529 Øveråsløken IV & 885-1015 e.Kr. & $1(2)$ & $520-1400$ \\
\hline & Lok 535 Øveråsløken V & 885-1015 e.Kr. & $1(2)$ & $290-1350$ \\
\hline & Gjermundnesåsane & 895-1015 e.Kr. & - & - \\
\hline & Lok 504 Sinderhaugen IV & 970-1025 e.Kr. & 2 & $110-1150$ \\
\hline & Lok 505 Sinderhaugen V & 975-1030 e.Kr. & 2 & $100-1150$ \\
\hline & Lok 508 Lunheim III & 1015-1050/1080-1150 e.Kr. & 2 & $560-770$ \\
\hline & Lok 515 Kvilet I & 1020-1160 e.Kr. & 2 & $800-1350$ \\
\hline & Lok 532 øveråsløken VI & 1030-1210 e.Kr. & 2 & $660-1700$ \\
\hline & Lok 601 Neråssetra & 1030-1210 e.Kr. & 2 & $850-1900$ \\
\hline & Lok 602 Øveråsløken VII & 1050-1085/1125-1140/1150-1225 e.Kr. & $1(2)$ & $900-1950$ \\
\hline & Lok 519 Flate I* & 1210-1275 e.Kr. & (1) & 2400 \\
\hline & Gjengstøen* & 1310-1360/1385-1425 e.Kr. & - & - \\
\hline \multirow{12}{*}{$\frac{\text { 을 }}{\text { 产 }}$} & Myrsethaugen & 1160-1270 e.Kr. & 2 & $350-1700$ \\
\hline & Veøya, kullgrop 2 & 1230-1370 e.Kr. & - & - \\
\hline & Lok 526 Øveråsløken I (526-KG II) & $1250-1290$ e.Kr. & (1) & 385 \\
\hline & Vaagland Indre & 1270-1305/1365-1385 e.Kr. & - & - \\
\hline & Veøya, kullgrop 5 & 1290-1420 e.Kr. & - & - \\
\hline & Veøya, kullgrop 5 & $1295-1425$ e.Kr. & - & - \\
\hline & Hennaelva & 1310-1360/1390-1430 e.Kr. & - & - \\
\hline & Veøya, kullgrop 1 & 1310-1430 e.Kr. & - & - \\
\hline & Veøya, kullgrop 3 & 1315-1435 e.Kr. & - & - \\
\hline & Sundet, lok $2^{*}$ & 1400-1435 e.Kr. & - & - \\
\hline & Veøya, kullgrop 4 & 1410-1445 e.Kr. & - & - \\
\hline & Sundet, lok 5 & 1510-1655 e.Kr. & - & - \\
\hline
\end{tabular}




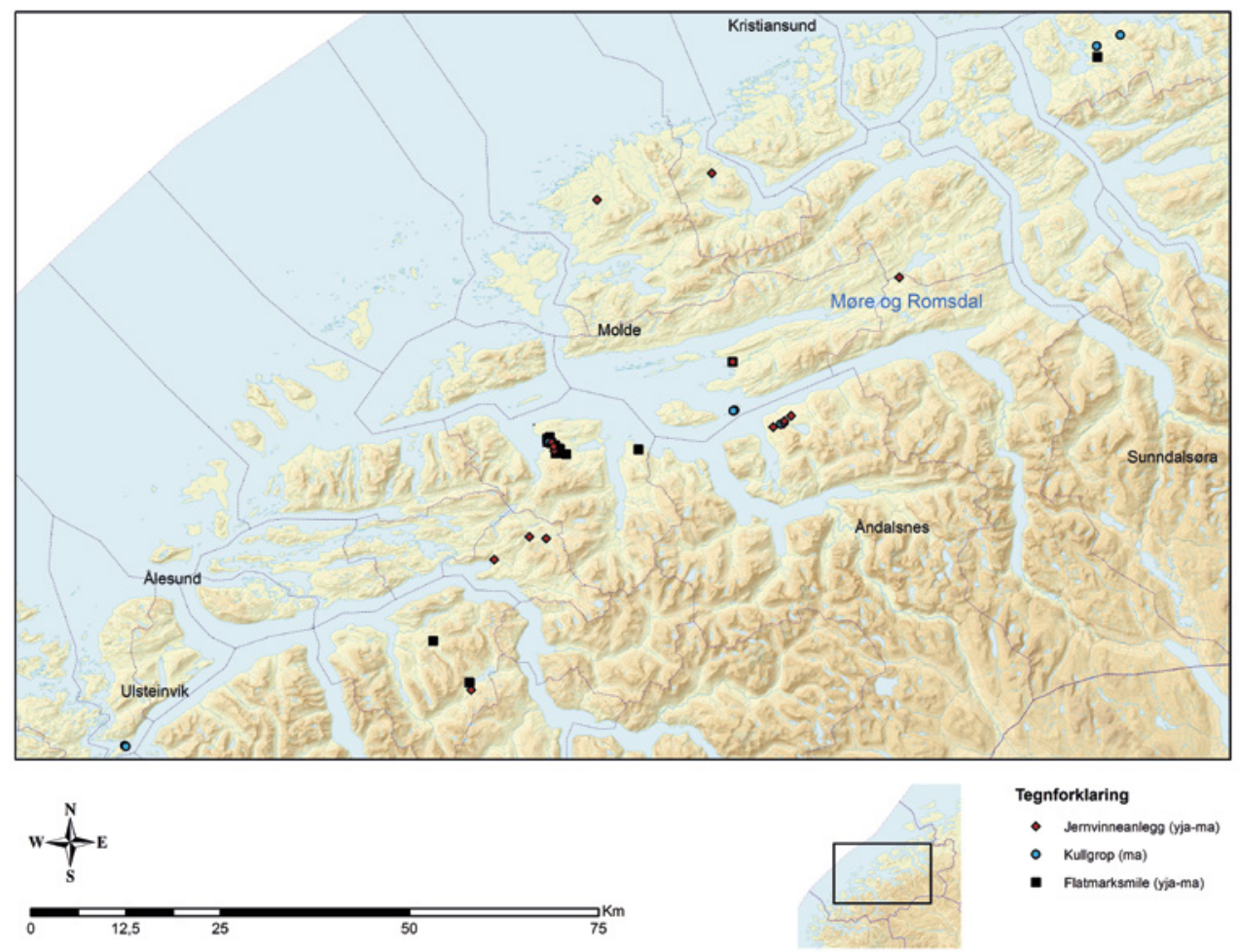

Figur 11. Oversikt over spredningen av jern-og kullfremstillingsanlegg datert til yngre jernalder og middelalder i Møre og Romsdal. Illustrasjon: Jo Sindre P. Eidshaug. Kartgrunnlag: Statens kartverk.

jernvinna. Vi har i denne artikkelen argumentert for at kullforekomstene som ble registrert i Vestnes i forbindelse med Møreaksen-prosjektet, kan representere spor etter tidlige flatmarksmiler, og at denne regionale kullbrenningstradisjonen først i høymiddelalderen ble avløst av brenning i grop.

Materialet fra Vestnes viser tydelig at flatmarksmilene inngår i en romlig og kronologisk sammenheng med jernvinna. Milene synes å ha utviklet seg over tid - først og fremst aner vi dette i form av økende dimensjoner. På det nåværende stadiet må vi likevel være varsomme med å trekke for vidtfavnende tolkninger når det gjelder utviklingstrekkene ettersom det foreligger stor usikkerhet rundt representativiteten til det foreliggende materialet. Avslutningsvis vil vi derfor gjøre oss noen betraktninger rundt mangelen på tidligere funn av førreformatoriske flatmarksmiler.

Først og fremst er det fristende å peke på manglende bevissthet om kulturminnetypen. Dette henger nok sammen med at kullgroptradisjonen er blitt ansett som den eldste i landet, til tross for at denne utviklingen ikke er redegjort for i alle landsdeler. Med andre ord er det ikke sikkert at utviklingstrekkene til kullbrenningstradisjonen fra Østlandet har overføringsverdi til Nordvestlandet. 
En annen faktor som har bidratt til manglende funn av eldre flatmarksmiler, er at de nesten ikke levner visuelle avtrykk i terrenget - især ikke der terrenget preges av tuer og andre naturlige kurver som maskerer kulturminnene. Illustrerende nok har for eksempel et hjelpemiddel som LiDAR meget begrensede potensialer i slike områder. Det ble demonstrert i en sammenligning av de registrerte kulturminnene i felt med de synlige anomaliene på LiDARdatasettet for Møreaksen (Eidshaug 2016a:43): Bortsett fra den mektige Sinderhaugen kunne bare ett utmarksminne (Lok 532, figur 8) identifiseres på LiDAR-datasettet.

Det faktum at sporene etter aktiviteter i utmarka er så utydelige i denne delen av landet, bør få konsekvenser for våre registreringsstrategier. Systematiske søk, der jordbor og spade benyttes aktivt uten at man i større grad skiller mellom overflateattributter (dvs. at man utelukkende stikker i hauger og groper), er nødvendige for å påvise disse kulturminnene. Det er også et poeng at funnene av de mulige tidlige flatmarksmilene bør få konsekvenser for hvordan man legger opp registreringsstrategien i andre deler av landet. Dette gjelder også steder der kullgropene ligger såpass tett at man lett overser muligheten for at det kan finnes spor etter andre kullfremstillingsformer.

Materialet fra Møreaksen-prosjektet har alt bidratt til nye tolkninger av en del tidligere registrerte lignende lokaliteter, slik som for eksempel kullokaliteten på Gjermundnes (Vik 2007), datert til 895-1015 e.Kr. (T-19505, tabell 2). Vi ser også tendenser til økt bevissthet rundt tidlige flatmarksmiler som en ny kulturminnekategori i Møre og Romsdal. Videre undersøkelser vil ikke bare være viktige for forskningen, men også for forvaltningen - slik at vi kan skape et godt kunnskapsgrunnlag og utvikle hensiktsmessige metoder for å forvalte denne kulturminnekategorien.

\section{Takk}

Takk til Bjørn Ringstad og andre tidligere og nåværende kolleger ved Kulturavdelinga til Møre og Romsdal fylkeskommune!

\section{Summary \\ Charcoal kilns in Vestnes from the Late Iron Age and Middle Ages}

This paper presents the first potential evidence of charcoal production prior to AD 1200 in Møre og Romsdal. During a recent archaeological survey, 16 charcoal deposits from the Late Iron Age and Middle Ages were discovered in the municipality of Vestnes. The authors argue that these deposits should be interpreted as charcoal kilns. Contrary to the common tradition in Late Iron Age and Medieval Norway of burning charcoal in pits, the new data suggest that charcoal was manufactured in charcoal kilns above the ground level, rather than in pits, prior to AD 1200 in Møre og Romsdal.

\section{Litteratur}

Berge, Ragnhild

2009 Archaeological Discoveries of Charcoal Pits in the Close Hinterland of Medieval Trondheim. Perspectives on Charcoal Production in Central Norway before and after the Turn of the 1st Millennium AD. I The 58th International Sachsen-symposium, 1-5 September. 2007, redigert av 
Terje Brattli, s. 110-133. Vitark 7. Acta Archaeologica Nidrosiensia. NTNU Museum of Natural History and Archaeology, Section of Archaeology and Cultural History and Tapir Academic Press, Trondheim.

2011a Arkeologisk undersøkelse av liggemile på Baklia, Trondheim bymark. Upublisert rapport, NTNU Vitenskapsmuseet, Seksjon for arkeologi og kulturhistorie.

2011b Kullbrenning i Baklia. SPOR 26(2):22-26.

Bloch-Nakkerud, Tom

1987 Kullgropen i jernvinna øverst $i$ Setesdal. Varia, vol. 15. Universitetets oldsaksamling, Oslo.

Dahle, Kristoffer

2007 Smiset på Holmemstranda - nokre tankar om busetjing og jarnframstilling i gamal tid. I

Romsdalsmuseet Arbok 2007, redigert av Jarle Sanden, s. 244-259. Romsdalsmuseet, Molde.

Damlien, Hege og Bernt Rundberget

2007 Kullgroper og kullproduksjon i Gråfjellområdet i Hedmark. Viking 70:155-170.

Eidshaug, Jo Sindre P.

2016a E39 Møreaksen - parsell Vik-Julbøen. Delprosjekt Bolungneset og Vik/Nerås, Vestnes kommune. Upublisert rapport, Møre og Romsdal fylkeskommune.

2016b E39 Møreaksen - parsell Vik-Julbøen. Delprosjekt Julbøen, Molde kommune. Upublisert rapport, Møre og Romsdal fylkeskommune.

2016c E39 Møreaksen - parsell Vik-Julbøen. Delprosjekt Nautneset og Heggdal, Midsund kommune. Upublisert rapport, Møre og Romsdal fylkeskommune.

Farbregd, Oddmund

1989 Tjørebrenning - ein enkel, men spennande kunst. SPOR 4(1):10-14.

Gundersen, Ingar M. og Camilla C. Wenn

2011 Ullsokningen og Kjyru-Tap - Ny kunnskap om tjæremila i førreformatorisk tid. Viking 74:241264.

Herteig, Asbjørn E.

1953 Innberetgning om topografisk-arkeologiske undersøkelser på Veøy, Veøy s. og prgjd., Romsdal i tiden juli-aug. 1953. Topografisk arkiv, Vitenskapsmuseet.

1954 Omkring kaupangen på Veøy i Romsdal. Viking 18:69-88.

Larsen, Jan Henning

2003 Lokalt initiativ og jernvinneforskningen i Snertingdal, Gjøvik kommune, Oppland. Et bidrag til forståelsen av jernutvinningen i eldre jernalder på Østlandet. Viking 66:79-104.

2004 Jernvinna på Østlandet i yngre jernalder og middelalder - noen kronologiske problemer. Viking 67:139-170.

2009 Jernvinneundersøkelser - Faglig program. Varia, vol. 78(2). Kulturhistorisk museum, Oslo.

Loftsgarden, Kjetil

2015 Kolgroper - gull eller gråstein? I Arkeologiske undersøkelser 2005-2006. Kulturhistorisk museum, Universitetet i Oslo, redigert av Inger Marie Berg-Hansen, s. 142-153. Portal forlag og Kulturhistorisk museum, Fornminneseksjonen, Oslo.

Loftsgarden, Kjetil, Bernt Rundberget, Jan Henning Larsen og Peter Hambro Mikkelsen

2013 Bruk og misbruk av C14-datering ved utmarksarkeologisk forskning og forvaltning. Primitive tider 15:59-69.

Lönnquist, Ulrika Stenbäck og Stig Welinder

2011 Att gräva i kolbottnar och kolarkojor. Fornvännen 106(3):205-214.

Melvold, Stine Annette, Margrete Figenschou Simonsen og Ellen Margrethe Storrusten

2010 Utgravningsprosjektet E6 Dal - Minnesund. Glimt fra fjorårets feltsesong. Nicolay 111:35-45.

Narmo, Lars Erik

1992 Delvis registrering av skogsbilveg Nerås, Vestnes kommune. Upublisert rapport, Møre og Romsdal fylkeskommune.

1996a Fra «kola men» til kullbrenner. Arbok for Norsk skogbruksmuseum: skogbruk, jakt og fiske $14: 23-53$ 
1996b Jernvinna i Valdres og Gausdal - et fragment av middelalderens økonomi. Varia, vol. 38.

Universitetets oldsaksamling, Oslo.

1997 Jernvinne, smie og kullproduksjon i Østerdalen. Varia, vol. 43. Universitetets oldsaksamling, Oslo.

Rundberget, Bernt

2007 Treart og datering. I Jernvinna i Gråfjellområdet. Gråfjellprosjektet, bind 1, redigert av Bernt Rundberget, s. 309-322. Varia, vol. 63. Kulturhistorisk museum, Oslo.

2013 Jernets dunkle dimensjon. Jernvinna i sørlige Hedmark. Sentral økonomisk faktor og premiss for samfunnsutvikling c. AD700-1300. Upublisert doktorgradsavhandling, Institutt for arkeologi, konservering og historie, Universitetet i Oslo, Oslo.

Solli, Brit

1996 Narratives of Veøy. An Investigation into the Poetics and Scientifics of Archaeology.

Universitetets oldsaksamlings skrifter. Ny rekke, vol. 19, Oslo.

Stenvik, Lars F.

2015a The bloomery in Mid-Norway: A retrospective glance and foresight. I Exploitation of outfield resources - Joint Research at the University Museums of Norway, redigert av Svein Indrelid, Kari Loe Hjelle og Kathrine Stene, s. 85-98. University of Bergen, Bergen.

2015b Fra malm og skog til jern og stål. Heimen 52:219-232.

Storrusten, Ellen Margrethe

2012 Flatmarksmile. Julsrud 42/5,6, Eidsvoll, Akershus. E6 prosjektet Dal-Minnesund rapport 5 av 6. Upublisert rapport, Kulturhistorisk museum, Universitetet i Oslo, Fornminneseksjonen, Oslo.

Tveiten, Ole

2005 Utkant eller egg? Jarnutvinning i Møre og Romsdal i førhistorisk tid og mellomalder. Upublisert Vik, Berit hovedfagsoppgave, Arkeologisk institutt, Universitetet i Bergen, Bergen.

2007 Arkeologisk registrering i samband med reguleringsplan for Gjermundnes Naturmurstein AS. Upublisert rapport, Møre og Romsdal fylkeskommune. 
